\title{
第35回 日本爬虫両棲類学会大会記録
}

\section{平成 8 年11月 9 日-11月 10 日 於横浜市立大学医学部}

\author{
The 35th Annual Meeting of the Herpetological Society of Japan \\ November 9-10, 1996, at Yokohama City University School of Medicine
}

\section{大会記事}

第 35 回日本爬虫両棲類学会大会は, 平成 8 年 11 月 9 日（土）と11月10日（日）の2 日にわたって神奈川県 横浜市金沢区の横浜市立大学医学部で開催された。前 日まで降り続いていた冷たい秋雨も上がり，薄曇りと いうまずまずの天気になった．横浜市の埋め立て地の 一番遠い隅にある「田舎大学」之はい之, 新交通之い 万全自動で，医学部前に停まる「シーサイドライン」 の捄陰もあって, 会員が続々と集まり, 当日参加者を 含め, 計145名が出席し, 受付の教室員, アルバイト 学生は大わらわだった。会場は300席もある医学部の 多目的ホールであったが，熱心で期待に満らた面々が そろらと, 委るで「満員御礼」の垂れ幕を下げたいよ らな雲囲気だった。と言らのも, 学会創立以来, 最大 の参加者人数であったからだ. 都心から 2 時間以上も かかり，遠く北海道から沖縄まで，日本の端から端末 での参加者が来ることを考虑して, 開会式は 9 日は午 前10:45から行われ，ゴリス会長と大会の準備委員会 代表の岸田令次教授の挨拶の後, 口頭発表を開始した。 申し込反発表は口頭 37 題, ポスター 20 題で, これも創 立以来の数であった。これだけの題数を会場一つで消 化するのは大変だったが, 参加者は熱心にすべてを聞 こうと長時間会場にこもり, 各題について活発な議論 毛行われた. 幸にも, 発表者と各座長の協力の扔陰で,

2 日間とも, 所定の時間内に終えることが出来た。. ス ライドもすべて手動式プロジェクターを使い，スライ ド受付の学生の手際の良さと, プロジェクター係の中 野, 船越両先生のうまい操作の批陰で, これも全く滞 りなく行われ，時間厳守に大きく貢献した，又，他の 学会で見られがらな，会場外でたむらして遊んだり休 んだりする参加者の姿がなく, 関係者も部外者も驚き, 感心し，「本当に専門分野の好きな者同士の集まりだ な」といらコメントがしばしば聞かれた。ポスター発 表は同会場の広い（と思った）明るい廊下で，10日の 午後に行われたが，一枚一枚全部見たい，話を聞きた い会員が多く，広いはずの廊下がたちまち狭くなり， 往来が不可能なぐらいだった，慈親会は 9 日夜, 付属 病院10階, レストラン「グリーン 八ウス」で開催さ れた，料理も酒も豊富でらまかったが，何より各分野 の情報交換が本御馳走であったよらで，抢開きになっ ても，なかなか皆さんは帰り難く名残を惜しんでいた。 貴重な休及時間を返上してまで本大会の成功に貢献し て下さった第 2 解剖学教室の岸田教授を始め, 雨宮助 教授, 門田講師, 跡部, 船越両助手, 院生の中村, 中 野, 日比谷の 3 先生, 6 人のアルバイト学生, その他 関係の皆様に深謝いたします。

(大会担当幹事, 学会長 R. ゴリス)

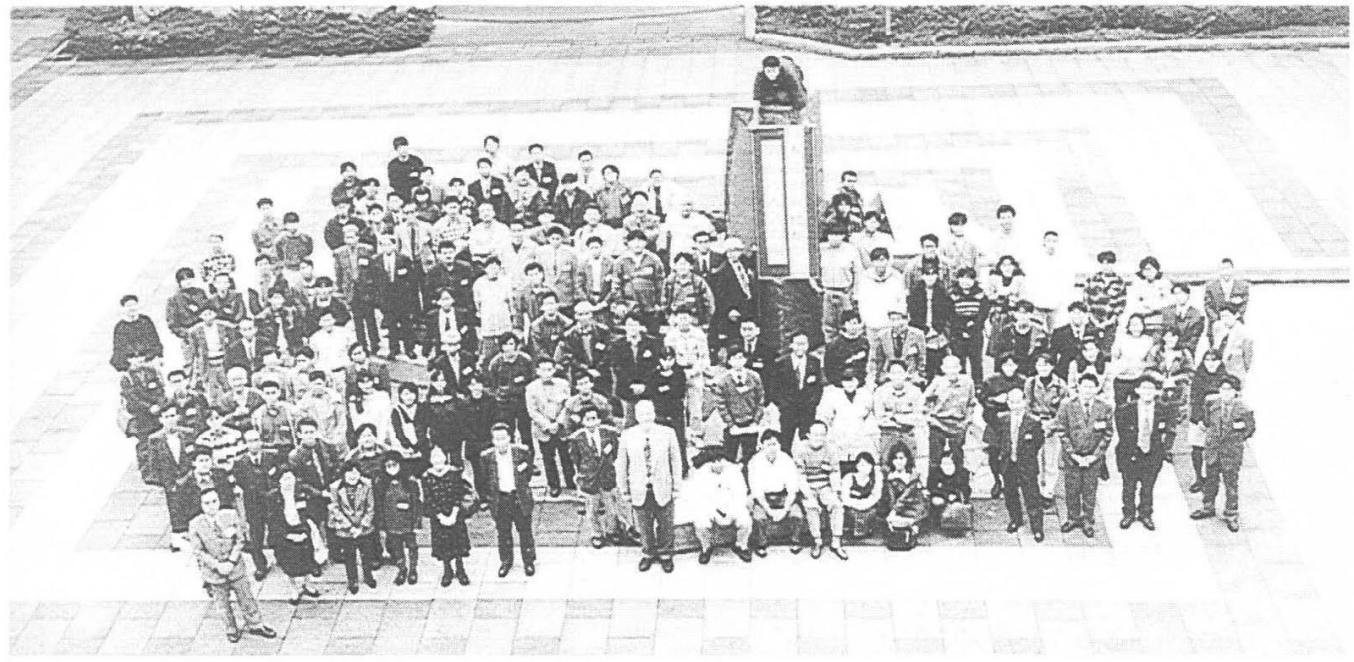

